\title{
SISTEM PEMBINAAN NARAPIDANA TERORISME DI LEMBAGA PEMASYARAKATAN KELAS IIB LAMONGAN
}

\author{
Munif Rochmawanto, S.H.,M.H. \\ Fakultas Ilmu Hukum, Universitas Islam Lamongan. \\ munif.rochmawanto@gmail.com
}

\begin{abstract}
ABSTRAKSI
Sistem pemasyarakatan diselenggarakan dalam rangka membentuk Warga Binaan Pemasyarakatan agar menjadi manusia seutuhnya, menyadari kesalahan, memperbaiki diri, dan tidak mengulangi tindak pidana sehingga dapat diterima oleh lingkungan masyarakat, dapat aktif berperan dalam pembangunan, dapat hidup secara wajar sebagai warga negara yang baik dan bertanggungjawab. Ini berarti bahwa tujuan akhir dari sistem pemasyarakatan adalah bersatunya kembali Warga Binaan Pemasyarakatan dengan masyarakat, sebagai warga negara yang baik dan bertanggung jawab, sehingga keberadaan mantan Warga Binaan di masyarakat nantinya diharapkan mau dan mampu untuk ikut membangun masyarakat dan bukan sebaliknya justru menjadi penghambat dalam pembangunan.
\end{abstract}

Kata Kunci : Narapidana, Terorisme, Lembaga Pemasyarakatan

\section{PENDAHULUAN}

Ketentuan Pasal 1 ke 3 UndangUndang Republik Indonesia Nomor 12 Tahun 1995 tentang Permasyarakatan, menyatakan bahwa :"Lembaga Permasyarakatan yang selanjutnya disebut LAPAS adalah tempat untuk melaksanakan pembinaan Narapidana dan Anak Didik Pemasya-rakatan”.

Tujuan sistem pemasyarakatan sebagaimana ditetapkan dalam Pasal 2 Undang-undang No. 12 Tahun 1995 tentang Pemasyarakatan dinyatakan bahwa "sistem pemasyarakatan diselenggarakan dalam rangka membentuk Warga Binaan Pemasyarakatan agar menjadi manusia seutuhnya, menyadari kesalahan, memperbaiki diri, dan tidak mengulangi tindak pidana sehingga dapat diterima oleh lingkungan masyarakat, dapat aktif berperan dalam pembangunan, dapat hidup secara wajar sebagai warga negara yang baik dan bertanggungjawab. Ini berarti bahwa tujuan akhir dari sistem pemasyarakatan adalah bersatunya kembali Warga Binaan Pemasyarakatan dengan masyarakat, sebagai warga negara yang baik dan bertanggung jawab, sehingga keberadaan mantan Warga Binaan di masyarakat nantinya diharapkan mau dan mampu untuk ikut membangun masyarakat dan bukan sebaliknya justru menjadi penghambat dalam pembangunan.

Soerjono Soekanto berbicara mengenai derajat efektivitas suatu hukum ditentukan antara lain oleh taraf kepatuhan warga masyarakat terhadap hukum, 
termasuk para penegak hukumnya. Sehingga dikenal suatu asumsi, bahwa : "Taraf kepatuhan hukum yang tinggi merupakan suatu indikator berfungsinya suatu sistem hukum. Dan berfungsi-nya hukum merupakan pertanda bahwa hukum tersebut telah mencapai tujuan hukum, yaitu berusaha untuk mempertahankan dan melindungi masyarakat dalam pergaulan hidup". Dalam ilmu sosial antara lain dalam sosiologi hukum, masalah kepatuhan atau ketaatan hukum atau kepatuhan terhadap kaidah-kaidah hukum pada umumnya telah menjadi faktor yang pokok dalam menakar efektif tidaknya sesuatu yang ditetapkan dalam hal ini hukum. ${ }^{1}$

Selain itu juga ditujukan untuk mengetahui kendala-kendala apa yang dihadapi di Lembaga Pemasyarakatan Kelas II Lamongan dalam melaksanaan pembinaan narapidana khusus teroris. Dengan pendekatan yuridis normatif penelitian ini diharapkan dapat menjadi gambaran yang lebih nyata mengenai efektivitas deradikalisasi dalam proses pembinaan narapidana terorisme di Lembaga Pemasyarakatan Kelas IIB Lamongan.

Berdasarkan Latar Belakang Masalah tersebut dapat disimpulkan permasalahan, bagaimana sistem pembinaan narapidana terorisme di Lembaga Pemasyarakatan Kelas IIB Lamongan?

\section{METODE PENELITIAN}

Oleh karena type penelitian yang digunakan adalah type penelitian yuridis normatif, maka pendekatan masalah yang digunakan adalah pendekatan perundangundangan (Statute Approach). Pendekatan tersebut melakukan pengkajian pengaturan perundang-undangan yang berhubungan dengan pokok permasalahan. Selain itu juga digunakan pendekatan konsep (Coceptual Approach), pendekatan ini maksudnya melihat konsep-konsep terkait dengan pembinaan narapidana teroris.

\section{Hasil Penelitian dan Pembahasan}

Program Deradikalisasi di Indonesia dilaksanakn oleh BNPT bekerjasama dengan berbagai pihak seperti polisi, Lembaga Pemasyarakatan, BNPT juga mendesain program resosialisasi dan reintegrasi, dengan cara membimbing mereka dalam bersosialisasi dan menyatu kembali dengan masyarakat. Selain itu deradikalisasi juga dilakukan melalui jalur pendidikan dengan melibatkan perguruan tinggi, melalui serangkaian kegiatan seperti public lecture, workshop, dan lainnya, mahasiswa diajak untuk berfikir kritis dan 
memperkuat nasionalisme sehingga tidak mudah menerima doktrin yang destruktif.

Upaya pemidanaan terhadap pelaku tindak pidana kasus terorisme perlu pembinaan yang khusus. Penanganan terorisme sebenarnya suatu perlawanan yang ditujukan kepada ideologi yang dianut teroris beserta penyebarannya. Program deradikalisasi menjadi penting karena memiliki peran untuk melepaskan ideology yang dianut oleh radikalis-teroris dengan menggantikannya dengan ideology Pancasila.

Adapun pembinaan yang dilakukan meliputi ;

a. Pembinaan kepribadian

b. Pembinaan kemandirian

c. Pembinaan kesadaran berbangsa dan bernegara.

Untuk pembinaan napi teroris petugas Lapas harus paham bahwa perlakuan terhadap mereka juga ada perlakuan khusus baik dalam pengawasan maupun pembinaan Perlakuan terhadap mereka lebih bersifat persuasif namun tidak mengesampingkan kewaspadaan pengamanan.

Berdasarkan data yang penulis peroleh dari Pegawai dan Narapidana Terorisme di Lembaga Pemasyarakatan Kelas IIB Lamongan dapat diketahui bahwa, terdapat dua spesifikasi tema dalam memandang pembinaan berbangsa dan bernegara yaitu : a. Sikap cukup menerima Pembinaan Berbangsa dan Bernegara

b. Sikap tidak menerima Pembinaan Berbangsa dan Bernegara.

Berdasarkan tema tersebut dapat diketahui bahwa masih ada narapidana terorisme yang dapat dibina baik wawasan berbangsa maupun wawasan bernegara, tetapi banyak juga yang menolak dengan tegas dilaksanakannya upacara kenegaraan.

Sistem pembinaan di Lembaga Pemasyarakatan Kelas IIB Lamongan sudah tergolong bagus, hal ini dikarenakan beberapa hal, yaitu :

a. Lapas Lamongan mempunyai Pamong yang merupakan salah satu pegawai Lembaga Pemasyarakatan kelas IIB Lamongan yang ditunjuk karena mempunyai kemampuan dan kecakapan lebih dalam keagamaan yang diharapkan mampu mendukung proses deradikalisasi bagi narapidana terorisme tentunya di dukung oleh semua Pegawai Lapas ;

b. Lapas Lamongan menjalin hubungan kerjasama yang baik dengan BNPT, TNI, Polri, para Tokoh Agama dan mantan narapidana terorisme yang telah kembali berwawasan kebangsaan yang tergabung dalam lingkar Perdamaian dengan juga berkordinasi dengan instansi pemasyarakatan lainnya, saling bertukar informasi, 
instansi penegak hukum lainnya, pondok pesantren, dan Majelis Ulama Indonesia guna pembinaan dan pelurusan akhlak.

c. Petugas jaga yang kooperatif, hal ini terbukti dengan pelaksanaan tugas penjagaan sudah sesuai dengan prosedur tetap yang ada ;

d. Fasilitas yang dimiliki oleh Lapas Lamongan cukup memadai untuk mendukung proses pembinaan Narapidana terorisme.

Kendala dalam penerapan program deradikalisasi ini muncul dari dua sisi. Pertama, dari sisi program deradikalisasi itu sendiri yang belum memiliki metode dan alat ukur yang jelas. Fokus dan sasaran program atau subyek deradikalisasi juga masih samar. Kedua program deradikalisasi hanya bersifat sporadis dan tidak mencakup semua sasaran.

Lembaga Pemasyarakatan Kelas IIB Lamongan merupakan suatu Lembaga Pemasyarakatan yang memiliki kualifikasi maximum security. Narapidana yang dibinapun bukan kategori rendah, banyak narapidana-narapidana yang beresiko tinggi dibina di Lembaga Pemasyarakatan tersebut, maka penanganan narapidana di sana bukan perkara mudah. Hal inilah yang menjadi kendala Lembaga Pemasyarakatan Kelas II B Lamongan.

\section{KESIMPULAN}

Dari hasil pembahasan yang telah diuraikan dalam bab dan sub bab, maka dapat disimpulkan bahwa sistem pembinaan narapidana khusus terorisme di Lembaga Pemasyarakatan Kelas II B Lamongan dilakukan melalui metodemetode pemencaran kamar hunian narapidana terorisme, dengan metode ini Narapidana terorisme menjadi bergerombol, mengurangi akses bertemu, bertukar pikiran, menyebarkan paham sesama narapidana terorisme.

DAFTAR PUSTAKA

A.C Manullang, Menguak Tabu Intelejen Teror, Motif dan Rezim, Panta Rhei, Jakarta, Januari 2001.

Johnny Ibrahim, Teori Metode Penelitian Normatif, Banyu Media Publishing, Malang 2005.

Peter Mahmud Marzuki. Penelitian Hukum. Universitas Air Langga. Surabaya. 2005.

Soekanto Soerjono, Faktor-faktor yang Mempengaruhi Penegakan Hukum. Rajawali, Jakarta 